\title{
マイクロ流路内における均一乳化液滴生成範囲の予測*
}

\author{
片山絵里香*1, 宮 本 哲 郎*1 \\ 富 樫 盛 典*1, 遠 藤 喜 重*2

\section{Predicting the Generation Range of Uniform Emulsified Droplets in a Micro-Channel} \\ Erika KATAYAMA*3, Tetsuro MIYAMOTO, \\ Shigenori TOGASHI and Yoshishige ENDO \\ *3 Mechanical Engineering Research Laboratory, Hitachi, Ltd., \\ 832-2 Horiguchi, Hitachinaka-shi, Ibaraki, 312-0034 Japan

\begin{abstract}
To simulate the emulsification process in a micro-channel, a computational fluid dynamics (CFD) technique, called the volume of fluid (VOF) method, was used. To improve computational accuracy, the mesh of the simulation model was divided finely enough and a parallel computation for a large-scale CFD simulation was executed to calculate the emulsified droplet generation process in a micro-channel. As a result, it was confirmed that the length of droplet position determined by the VOF method agrees well with the experimentally measured within an error of $5 \%$. In accordance with that agreement between calculation and experiment, a map of the generation of uniform emulsified droplets was constructed by using the VOF method. The map is defined by two dimensionless parameters: Reynolds number $(\mathrm{Re})$ and Capillary number $(\mathrm{Ca})$. It is clear from the map that the generation of droplets peaks at $R e$ of 3.0 to 4.0 and $C a$ of $10.0 \times 10^{-3}$. The map makes it possible to generate emulsified droplets experimentally within a coefficient of variation $\left(C_{V}\right)$ of $5.0 \%$.
\end{abstract}

Key Words: Micro-Channel, Multi-Phase Flow, Computational Fluid Dynamics, Liquid Droplet

\section{1. 緒言}

乳化とは, 水と油のように互いに混じり合わない液 体の一方を微細化して液体中に分散させ乳化液の状態 にすることをいい, 化学品や食品, 医薬品等各種産業 において広く使用されている。これまでの主な乳化方 式として，バッチ法と㭔ばれる機械的攪汼によるもの が一般的であった。しかし，垷汼による混合むらが原 因で, 乳化液滴径の制御は容易でなく, また, 生成し た乳化液滴径が不均一であることが課題であった(1).

これら課題を解決するために, 近年, 均一で微小な 乳化液滴の生成技術としてマイクロ流体デバイスが注 目されている(2). 直径数 $\mu \mathrm{m}$ 加ら数百 $\mu \mathrm{m}$ の微細な流 路を有するマイクロ流体デバイスは，(1)マイクロ流 路内の安定した層流中で乳化液滴が生成するため, 液 滴径のばらつきが小さい，(2)水と油の流速を制御す ることにより, 液滴径の制御が可能, ( 3 ) 液滴の生成 時間が短い, といった特徵を持つ ${ }^{(3)}$.

* 原稿受付 2009 年 4 月 24 日.

*1 正員, (株) 日立製作所機械研究所(覀312-0034 ひたちなか 市堀口 832-2).

*2 (株) 日立プラントテクノロジー土浦研究所( $300-0013 \pm$ 浦市神立町 603)。

E-mail : erika.katayama.vs@hitachi.com
マイクロ流体デバイスの乳化に関して, 現在までに 以下のことが実験的に検討されている. 西迫ら(4) (6) は $\mathrm{T}$ 字型マイク口流路で, 粒子径の制御や多量処理

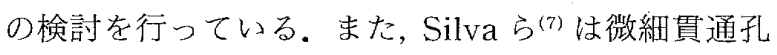
を通して液滴を生成する貫通型流路を採用し, 送液速 度と液滴径の関係性について検討している。更に, 村 上ら ${ }^{(8)}$ は, マイクロ流路を上流側から分岐し, 分峠部 で液滴を分割する液滴生成方法を確立した。

一方, 流体解析による予測で注, Davidson ら ${ }^{(9)}$ が $^{\circ}$ Volume of Fluid(VOF) 法(10)で解析し, 実験と解析結 果の液滴形状の比較を行っている. 同様に小林ら(11) は, 貫通型流路における流路断面のアスペクト比が乳 化液滴生成のしやすさに関係することを, VOF 法に よる解析で明らかにし，実験で検証している。更に， 原田ら (12)(13) は, $\mathrm{T}$ 字型マイク口流路を対象として, 生成した液滴径を予測する Moving Particle SemiImplicit (MPS) 法の三次元解析コードを開発した。

しかし, 対象とする流体の物性值や二液合流部の流 路幅が液滴生成条件に与える影響を, 様々な条件で網 羅的に検傠することは, 実験では困難である。また, これまでの流体解析において，マイクロ流路内の均一 な乳化液滴生成の可否を評価し, 設計に適用した事例 は見当たらない.そこで本研究では，(1)大規模な並 
列計算でVOF 法による水と油の二相流解析を行い, マイクロ流路内の乳化現象を精度良く解析すること， (2)解析結果を基に, 無次元数で整理し, 様々な物性 値や流路幅に対して汎用的に適用できる均一乳化液滴 生成範囲の予測力法を確立すること, (3) 予測した均 一乳化液滴生成条件から等験条件を抽出し, 均一な液 滴を生成することを，研究の目的とした。

\section{2. 記 号・単 位}

$$
\begin{aligned}
C & : \text { 体積分率 } \\
C_{V} & : \text { 変動係数 } \% \\
D & : \text { 流路幅 } \mathrm{m} \\
f_{\mathrm{int}} & : \text { 㽞面張力項 } \mathrm{N} / \mathrm{m}^{3} \\
g & : \text { 重力加速度 } \mathrm{m} / \mathrm{s}^{2} \\
p & : \text { 圧力 } \mathrm{Pa} \\
t & : \text { 時間 } \mathrm{s} \\
U & : \text { 速度 } \mathrm{m} / \mathrm{s} \\
\mu & : \text { 粘性係数 } \mathrm{Pa} \cdot \mathrm{s} \\
\rho & : \text { 密度 } \mathrm{kg} / \mathrm{m}^{3} \\
\sigma & : \text { 標準偏差 } \\
\gamma & : \text { 界面張力 } \mathrm{N} / \mathrm{m} \\
\bar{\varphi} & : \text { 平均液滴径 } \mathrm{m} \\
\tau & : \text { 応力テンソル } \mathrm{N} / \mathrm{m}^{2} \\
R e & : \text { レイノルズ数 } \\
C a & : \text { キャピラリー数 }
\end{aligned}
$$

添 字

$c ：$ 連続相

$d:$ 分散相

\section{VOF 法による二相流解析}

$3 \cdot 1$ 解析手法 解析には, 水と油のように明瞭 な界面で分離された相互に混じりあわない自由表面流 に適用可能な VOF 法を用いた。VOF 法では，分散相 と連続相の界面を, 計算しているメッシュ内部の流体 の総体積に対する分散相の比率変数として解く. 以下 に，基礎方程式を示吉。質量保存式は式(1), 運動方 程式は式（2）で表される，運動方程式では，Brackbill(14) らの考案したCSF (Continuum Surface Force）モデルに基づく，界面張力で誘起された力を表 す項 $f_{\text {int }}$ を追加した(15).

$$
\begin{aligned}
& \frac{\partial \rho}{\partial t}+\nabla \cdot(\rho \boldsymbol{U})=0 \cdots \cdots \cdots \cdots \cdots \cdots \cdots \cdots \cdots \cdots \cdots \cdots \cdots \cdots \cdots \cdots \\
& \frac{\partial(\rho \boldsymbol{U})}{\partial t}+\nabla \cdot(\rho \boldsymbol{U} \boldsymbol{U})=-\nabla p+\nabla \cdot \tau+\rho g+f_{\mathrm{int}}
\end{aligned}
$$

VOF (体積分率)の輸送方程式は式 (3)で表される。

$$
\frac{\partial C}{\partial t}+\nabla \cdot(C \boldsymbol{U})=0
$$

ここで，Cは体積分率を表し，連続相に対する值は $C=0$, 分散相は $C=1$ となる。また, 界面は $C=0.5$ となるメッシュの位置で表現される．基礎方程式 (1) 〜 (3) を解くことにより，解を導出する.

流体の密度 $\rho$ と粘性係数 $\mu$ は, 式 (4)，（5）に示す ように，体積分率 $C$ を用いて算術平均で求められる。

$$
\begin{aligned}
& \rho=\rho_{c}(1-C)+\rho_{d} C \\
& \mu=\mu_{c}(1-C)+\mu_{d} C
\end{aligned}
$$

VOF 法は一般的に, 輸送方程式を解く際の数值拡 散が原因で，界面の位置が不明確となる。そこで， CIP (Cubic-Interpolated Propagation)法(16)のよう に数值拡散を抑える解析手法もあるが，本研究では， 液滴生成部の短い領域を解析対象としており，後述す る通り，液滴を捕らえるのに十分なメッシュ解像度を 有しているため, 数值拡散の影響は少ないと考光, VOF 法を適用した。

$3 \cdot 2$ 解析モデルと解析条件 図 1 に $\mathrm{T}$ 字型マイ クロ流路の乳化液滴生成模式図を示す。本研究では以 降，液滴となる油を分散相，水を連続相とする。マイ クロ流路内では, スケールを小さくすることで体積に 対し界面積の占める割合が大きくなる。そのため, 慣 性力(体積力)に比心二液の界面に働くせん断力や界面 張力 (面積力) が支配的となり液滴が生成する. 流路幅 Dのマイクロ流路に連続相と分散相を種々の流量比 で供給すると，二液の界面にはせん断力が掛かり，せ ん断された分散相は界面張力の効果で液滴となる。そ こで, 解析結果はせん断力と界面張力の効果表す無 次元数 $\operatorname{Re}$ (レイノルズ数) と $\mathrm{Ca}$ (キャピラリー数)で 整理する. $R e$ と $C a$ の定義を式 $(6) ，(7)$ に示す。

$$
\begin{aligned}
& R e=\frac{\rho_{c} U_{c} D}{\mu_{c}} . \\
& C a=\frac{\mu_{d} U_{d}}{\gamma} .
\end{aligned}
$$

計算条件は表 1 に示す通りである。西迫ら(6)の実験 の結果より,マイクロ流路内で生成する主な乳化液滴

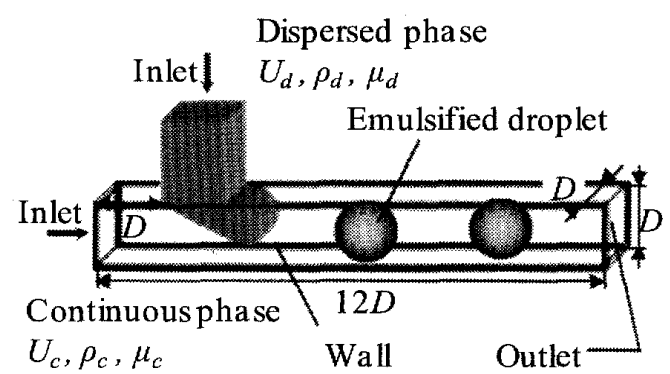

Fig. 1 Schematic of T-junction micro-channel 
径の範囲は，流路幅の 0.6 2.5 倍程度になることが 分かっている。そこで, 流路幅の 0.6 倍の液滴を精度 よく解析できるよう，液滴の体積の誤差を $1 \%$ 以内に 抑える総メッシュ数 $7.5 \times 10^{5}$ に決定した。 また，更 にメッシュを細かく分割した場合との結果を比較した ところ, 生成する液滴の形状や生成位置, 大きさが汇 ぼ一致しており，解析結果に影響が無いことが分かっ た。

計算には並列型スーパーコンピュータ SR 11000 (日

Table 1 Analysis condition using VOF method

\begin{tabular}{|c|c|c|}
\hline \multicolumn{2}{|c|}{ The number of meshes } & $7.5 \times 10^{5}$ \\
\hline \multicolumn{2}{|c|}{ The number of time steps } & 100 \\
\hline \multicolumn{2}{|c|}{ Time step (s) } & $3.0 \times 10^{-5}-3.0 \times 10^{-3}$ \\
\hline \multicolumn{2}{|c|}{ Computational time (s) } & $500-1000$ \\
\hline \multicolumn{2}{|c|}{$\operatorname{Re}$} & $0.01-100$ \\
\hline \multicolumn{2}{|c|}{$C a$} & $1.0 \times 10^{-4}-1.0 \times 10^{-1}$ \\
\hline \multicolumn{2}{|c|}{$U_{c} U_{d}$} & $3.4 \times 10^{-4}-3.4 \times 10^{3}$ \\
\hline \multicolumn{2}{|c|}{ Inlet boundary condition } & Constant velocity \\
\hline \multicolumn{2}{|c|}{ Wall boundary condition } & No-slip \\
\hline \multicolumn{2}{|c|}{ Outlet boundary condition } & Free outlet \\
\hline \multicolumn{2}{|c|}{$\begin{array}{l}\text { Wall contact angle for dispersed phase } \\
{\left[{ }^{\circ}\right]}\end{array}$} & 180 \\
\hline \multicolumn{2}{|c|}{ Interfacial tension $[\mathrm{N} / \mathrm{m}]$} & 0.01 \\
\hline & $\begin{array}{c}\text { Continuous } \\
\text { phase }\end{array}$ & $\begin{array}{l}\text { Dispersed } \\
\text { phase }\end{array}$ \\
\hline Density $[\mathrm{kg} / \mathrm{m} 3]$ & 997 & 1107 \\
\hline Viscosity [mPa's] & 1.00 & 0.17 \\
\hline
\end{tabular}

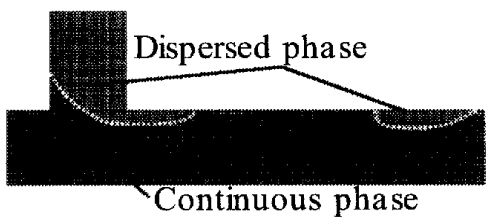

(a) $180^{\circ}$

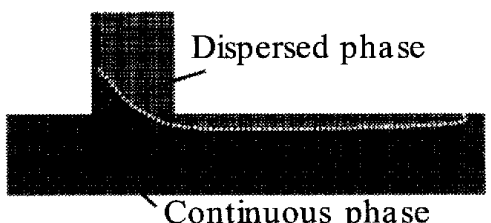

(b) $135^{\circ}$

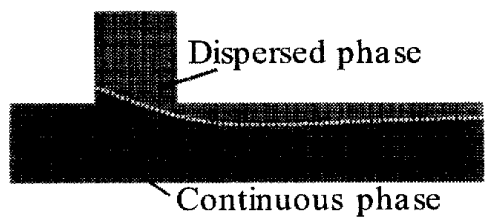

(c) $90^{\circ}$

Fig. 2 Effect of wall contact angle for dispersed phase
立製，最大 62.2 TFLOPS)の $64 \mathrm{CPU}$ (Central Processing Unit)のうち $8 \mathrm{CPU}(7.8$ TFLOPS)を利 用し，計算時間は 1 ケース当たり約 500 1 000 sとな る.

分散相の壁面に対する接触角について, 解析により 検討を行った。結果を図 2 に示す。接触角 $135,90^{\circ}$ の条件では，壁面への濡れ性が強いため，分散相が壁 面に沿った流れを形成する。一方，接触角 $180^{\circ}$ の壁 面八濡れない(親水性) 条件では, 分散相がせん断され, 液滴となる，実際のマイクロ流体デバイスを作製する 際にも, 油滴を生成する場合には, 油滴生成部の流路 表面を親水性にすることが望ましく(4), 解析にお打る 接触角は $180^{\circ}$ と決定した。

境界条件は，入り口境界は一様流入(Constant velocity) 条件, 壁面境界はすべりなし $\left(\mathrm{No}^{-} \mathrm{slip}\right)$ 条件 とし，出口境界は自由流出(Free outlet）とした。

\section{4. 解析結果と実験による解析の検証}

$4 \cdot 1$ 解析結果 マイクロ流路内の乳化に, VOF 法による二相流解析を適用した解析結果を図 3 に示 す。ここで, Re の值は連続相の流量に比例する。図 3 ( a ) $R e=2.0$ の条件では，分散相が連続相の流路に 対し垂直方向から流入することで分散相がせん断さ れ，液滴が生成する。一方，図 $3(\mathrm{~b}) R e=0.1$ の条件 では，分散相に対し連続相の流量が少なすぎるため, せん断の効果が小さく, 液滴が生成しない.

$4 \cdot 2$ 可視化実験による解析の検証 VOF 法によ る二相流解析の妥当性を確認するため, 解析と可視化 美験の結果比較を行った。な晾, 実験には, 連続相と してアラビアガム水溶液, 分散相としてシリコンオイ ルを用いた．アラビアガム水溶液の濃度は, 2 9 wt\%(質量パーセント)とした。実験に用いた液体の 物性值を表 2 に示す。更に，可視化実験の模式図を図 5 に示す，実験方法は，シリンジポンプ(Harvard 製, PHD 2000)にて二渡を送液し，マイクロ流路内の乳化 状態を顕微鏡(スカラ製，VL-11SL)に接続したビデ

Table 2 Physical properties of two liquids (298 K)

\begin{tabular}{c||c|c}
\hline Properties & $\begin{array}{c}\text { Continuous } \\
\text { phase }\end{array}$ & $\begin{array}{c}\text { Dispersed } \\
\text { phase }\end{array}$ \\
\hline $\begin{array}{c}\text { Density } \\
{\left[\mathrm{kg} / \mathrm{m}^{3}\right]}\end{array}$ & $990-1030$ & $875-915$ \\
\hline $\begin{array}{c}\text { Viscosity } \\
{[\mathrm{mPa} \cdot \mathrm{s}]}\end{array}$ & $1.80-8.70$ & $1.80-5.00$ \\
\hline $\begin{array}{c}\text { Wall contact angle } \\
\left.\text { for oil [ }{ }^{\circ}\right]\end{array}$ & \multicolumn{2}{|c}{$70-100$} \\
\hline $\begin{array}{c}\text { Interfacial tension } \\
{[\mathrm{N} / \mathrm{m}]}\end{array}$ & $0.026-0.035$ \\
\hline
\end{tabular}




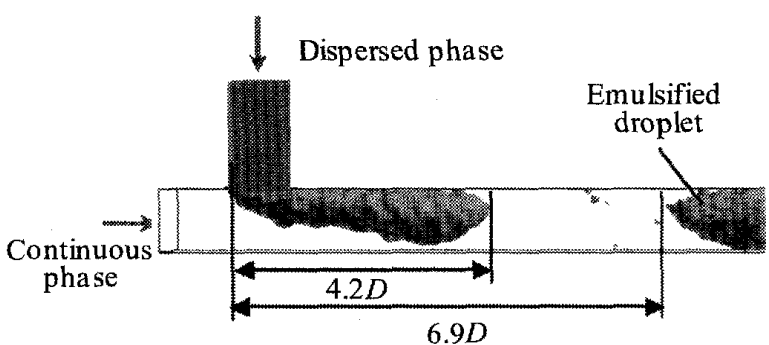

(a) $R e=2.0, C a=6.0 \times 10^{-3}(t=0.3 \mathrm{~s})$

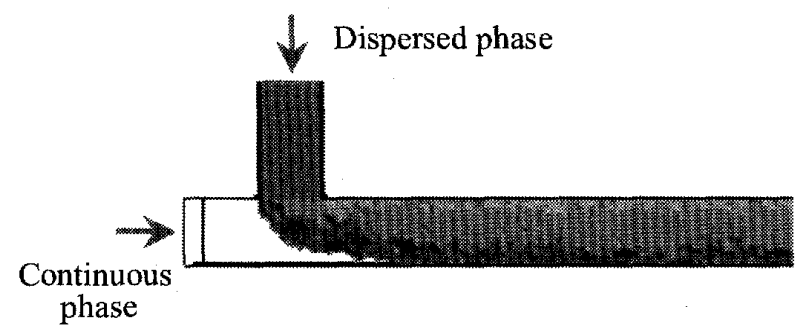

(b) $R e=0.1, C a=6.0 \times 10^{-3}(t=0.3 \mathrm{~s})$

Fig. 3 VOF method results of two-phase flow pattern

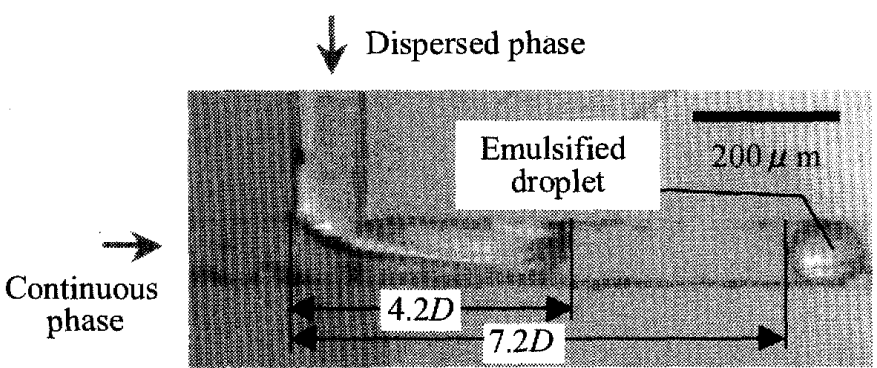

(a) $R e=2.0, C a=6.0 \times 10^{-3}(t=0.3 \mathrm{~s})$

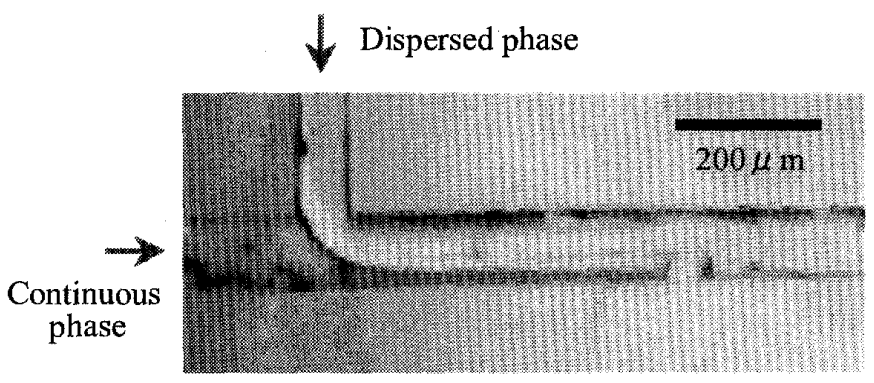

(b) $R e=0.1, C a=6.0 \times 10^{-3}(t=0.3 \mathrm{~s})$

Fig. 4 Experimental results of two-phase flow pattern

オカメラにて観察した. ビデオカメラで撮影した画像 はPCに取り込んで編集した。また，乳化液滴径の評 価にはデジタルマイクロスコープ(キーエンス製, VHX-500 F)と画像処理ソフトを用いた。

可視化実験に用いたマイクロ流体デバイス(ガラス 製)を図 6 に示す。図 4 では，静止した状態における 連続相中の分散相のガラ又壁面に対する接触角㹥 $70^{\circ}$ となる。しかし，実験では，予め連続相を送液して流

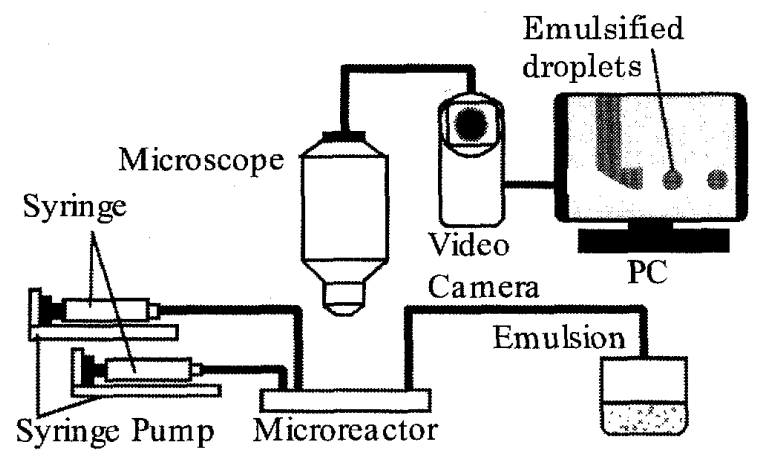

Fig. 5 Experimental setup for visualization

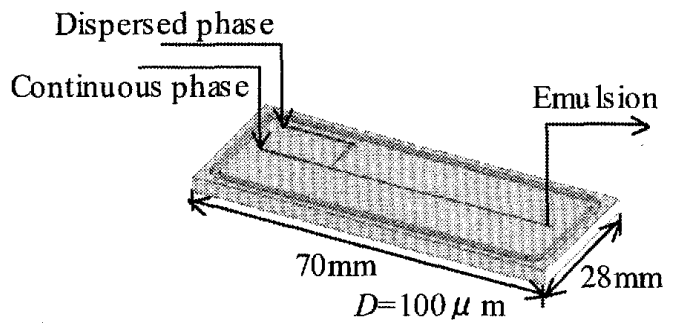

Fig. 6 Schematic of the microfluidic device

路内部を満たした後, 分散相の送液を開始する。その ため, 送液開始直後では, 連続相が流路壁面に液膜を 形成し，接触角は $180^{\circ}$ になると考えられる。

図 3 に示す解析との比較のため, 可視化実験結果を 図 4 に示す。同時刻に扔ける解析と実験の結果は, 液 滴生成位置が良く一致している，具体的には，流路幅 $D$ に対し，解析では $6.9 D$, 実験では $7.2 D$ となり, 䛊差が $4.3 \%$ となる.このことから, 十分なメッシュ 解像度の解析モデルを大規模な並列計算機を用いて言十 算することで, マイクロ流路内の乳化液滴生成現象を 短時間で精度良く解析できることを確認した。

\section{5. 無次元数による乳化マップ}

$5 \cdot 1$ 無次元数による乳化マップの作成 4 章で VOF 法による二相流解析が実験結果と一致すること を確認したため, 様々な条件に適用可能な乳化液滴生 成範囲の予測を行った。

乳化マップの作成プロセスを図7に示す、マイクロ 流体デバイスでは代表長さが短いので，Re は 1 を基 準とし，0.01〜100の簌囲で解析を行った。また，Ca は連続相と分散相の流量比が 1 程度となる $10^{-3}$ を基

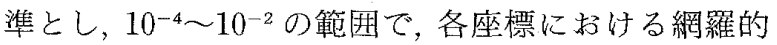
な解析を行った. 更に, 解析結果を体積分率 $C \geqq 0.5$ の分散相が存在する領域を表示し, 画像処理により液 滴生成可否の評価を行った。その結果, $C a$ が $10^{-3}$ の 範囲において，分散相がせん断され液滴となる領域と， 


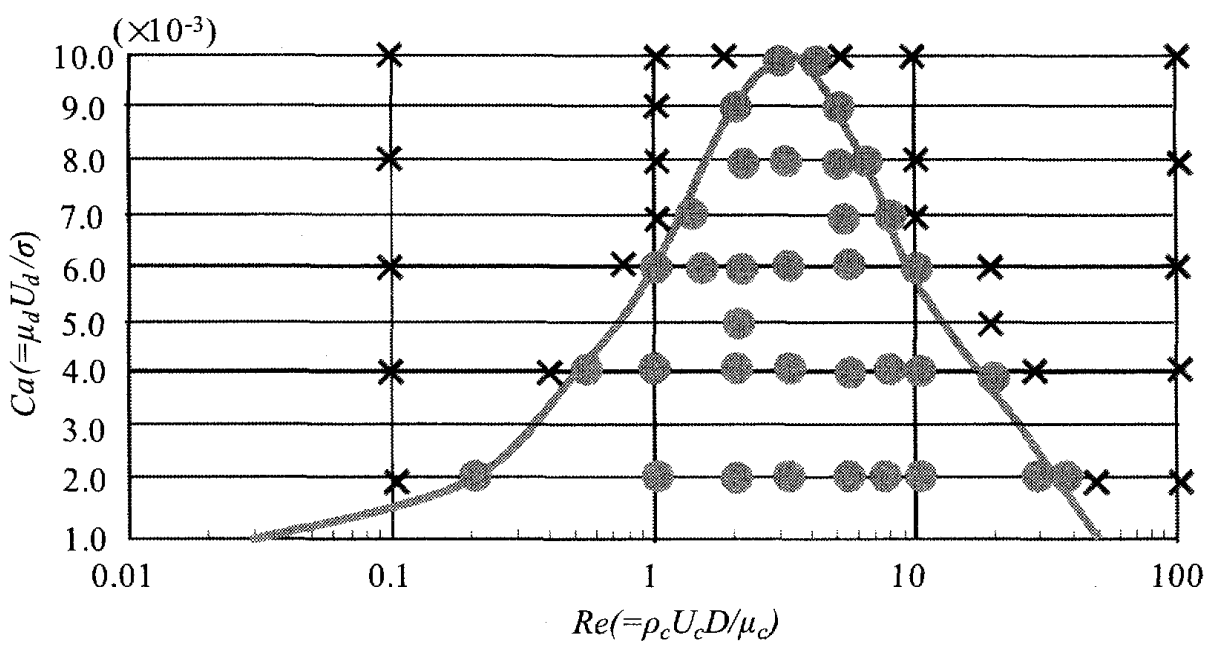

Fig. 7 Process of making the map from the VOF simulation results

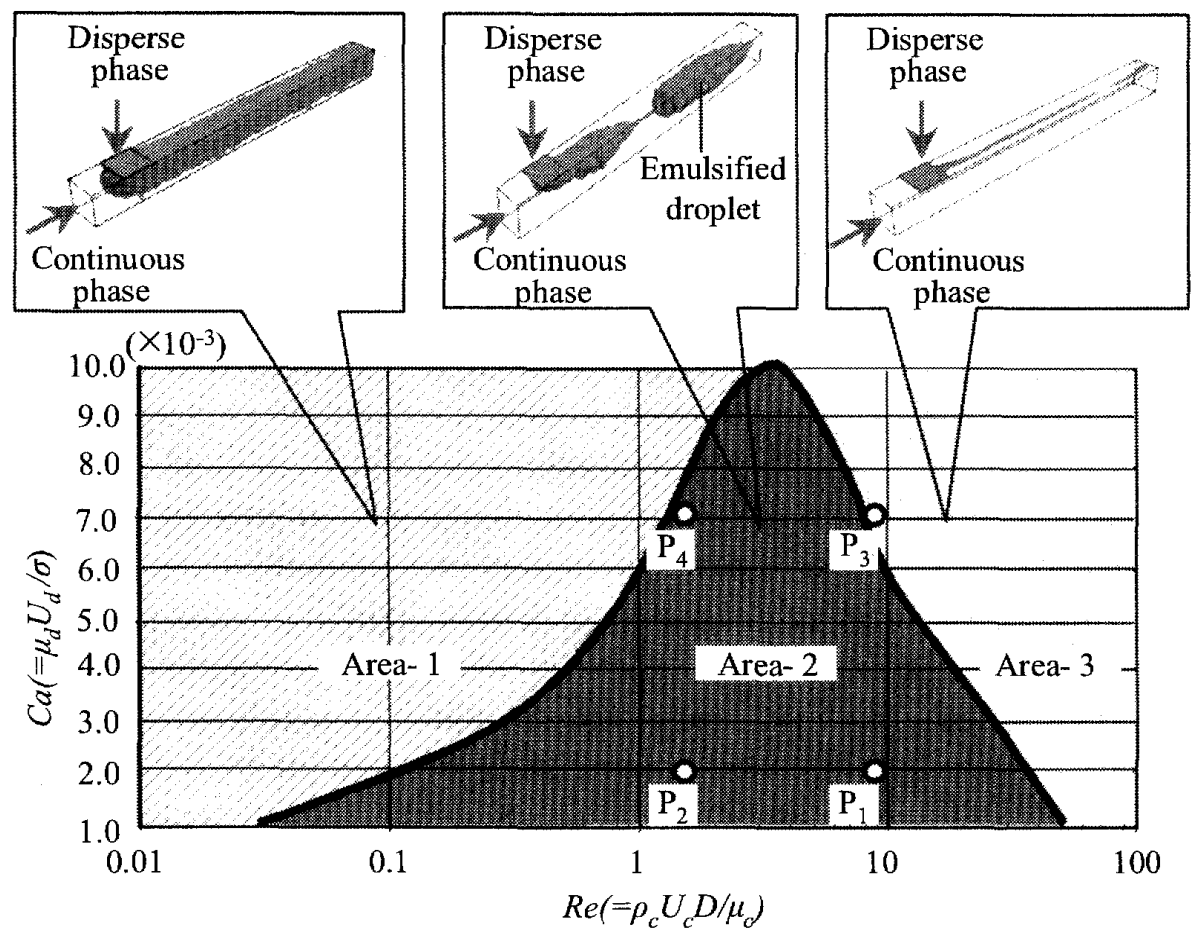

Fig. 8 Map of the emulsified droplet generation area obtained by the results of VOF simulation

液滴とならず層流を形成する領域が存在することを明 らかにした，更に，分散相がせん断された領域の座標 点付近を細かく分割し，解析を行うことで, 乳化領域 の境界を決定した。

作成した乳化マップを図 8 に示す。戍 8 より，乳化 液滴が生成する領域 $2($ Area-2) は, $R e=3.0 \sim 4.0$, $C a=10.0 \times 10^{-3}$ をピークとする山型分布となること が分かった。

山型分布外部領域に着目すると, 図 8 の領域 1(Area-1)では分散相に対し連続相の流量が少ないた め, 連続相により分散相がせん断されることなく, 流

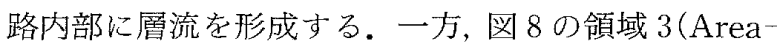

3)では分散相に対し連続相の流量が多いため, 分散相 が細い層流流れを形成する。このことから，液滴生成 には連続相と分散相の流量バランスが重要なことが理 解できる。

$5 \cdot 2$ 実験による乳化マップの検証＼cjkstart最後に, 無 次元数で整理した乳化マップの検証と生成する乳化液 滴径の評価を行った，均一化の評価指慗には，変動係 数 $C_{V}$ (Coefficient of variation) 值を用いた。 $C_{V}$ 值と は標準偏差 $\sigma$ と平均乳化液滴径 $\bar{\varphi}$ の比を百分率であ らわしたものであり, 式(8)で表される。

$$
C_{V}=\frac{100 \sigma}{\bar{\varphi}}
$$




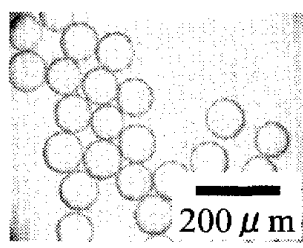

(a) $\operatorname{Re}=8.9$

(Fig. 6-P $)$

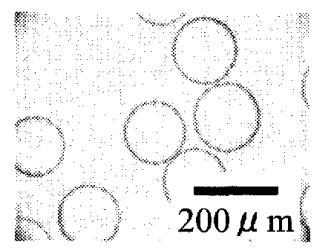

(b) $R e=1.8$

(Fig. 6- $\mathrm{P}_{3}$ )

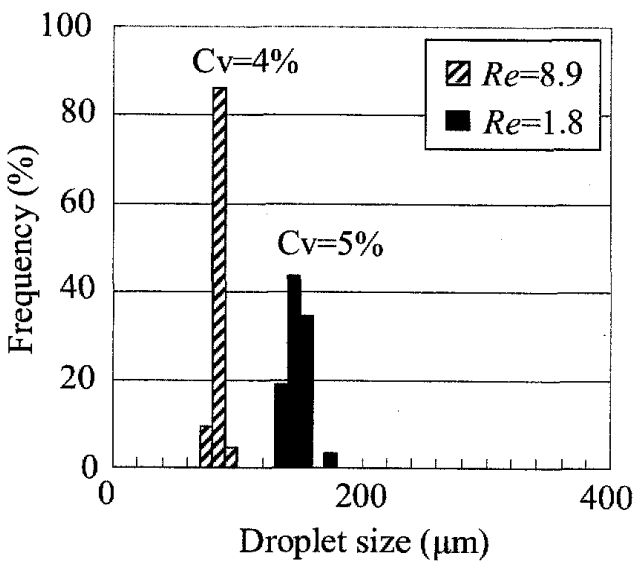

(c) Droplet size distribution

Fig. 9 Photograph and size distributions of the emulsified droplets $\left(C a=1.2 \times 10^{-3}\right)$

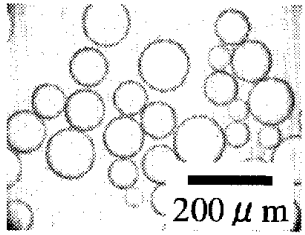

(a) $\mathrm{Re}=8.9$

(Fig. 6-P $)$

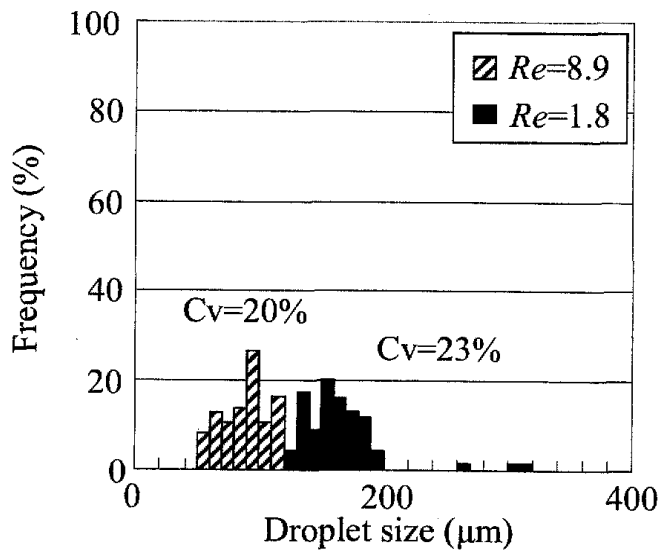

(c) Droplet size distribution

Fig. 10 Photograph and size distributions of the emulsified droplets $\left(\mathrm{Ca}=7.1 \times 10^{-3}\right)$

生成する乳化の液滴写真と液滴径分布を図 9,10 に示 す.図 $9(a),(b)$ 注図 8 の領域 2 内部 $P_{1}, P_{2}$ に示す 条件で検証した実験結果である。更に，図 $9(c)$ は液
滴写真をもとに画像処理ソフトで解析した液滴径分布 である。このことから，領域 2 内部の条件では，生成 する液滴径がシャープな分布となって扔り，また， $C_{V}$ 值が $5 \%$ 以内となることが分かった。

一方，図 10 は領域 2 の境界線付近の条件であり，図 10 (a) は図 8 の点 $\mathrm{P}_{3}$, 図 10(b) は図 8 の点 $\mathrm{P}_{4}$ で作製 した乳化液滴の写真である. 図 10( c) 蚁図 9(c)同様 に評価した液滴径分有である。山型分布の境界線付近 では $C_{V}$ 值が $20 \%$ を超え，生成する液滴径が大きくば らついていることが分かる，先述した通り，マイクロ 流体デバイスにおける乳化では，体積力と面積力のど ちらか一方の力が大きく働くことで液滴生成の可否が 決定される。しかし，山型分布の境界領域では，それ らの力が均衡状態にある。そのため, 解析では体積力 が支配的な二相に分かれた層流を形成する領域であっ ても，実験では不規則な摇らぎや乱れなどの外力が界 面に加わることで，体積力と界面に働く面積力のバラ ンスが崩れ，ばらつきながらも液滴が生成する。この ことから,領域 2 の山型分布境界線に近づく程, 体積 力と面積力のバランスが不安定になり，均一な乳化液 滴を得ることが困難となることが分かる。

以上より，VOF 法による二相流解析結果加ら $R e$ と Caで体系化した乳化マップが, 均一な乳化液滴生 成範囲の予測に適用できる見通しを得た。

\section{6. 結言}

マイクロ流路内に括ける均一乳化液滴生成範囲の予 測を対象に, VOF 法に上る二相流解析を行い，実験に よる検証から以下の結論を得た。

（1）大規模な並列計算と, 液滴形状を精度良く解 析するのに十分なメッシュ解像度を有することで，マ イクロ流路内の乳化液滴生成現象を誤差 5\%以内で精 度良く解析できることを実験で確認した。

（2）無次元数で整理した乳化マップから，乳化液 滴生成範囲は $R e=3.0-4.0, C a=10.0 \times 10^{-3}$ をピー クとする山型分布となることを明らかにした。

（3）乳化マップより均一な乳化液滴生成範囲内に おける条件でマイクロ流体デバイスを用いた実験的檢 証の結果，液滴径のばらつきを表す $C_{V}$ 值が $5 \%$ 以内 の均一乳化を実現した。

\section{文献}

(1) Graaf, S., Steegmans, M. L. J., Sman, R. G. M., Schroen, C. G. P. H. and Boom, R. M., Droplet Formation in T-Shaped Microchannel Junction: A Model System for Membrane Emulsification, Colloids and Surfaces A: Physicochemical and Engineering 
Aspects, Vol. 266 (2005), pp. 106-116.

(2) Hessel, V., Hardt, S. and Lowe, H., Chemical Micro process Engineering: Fundamentals, Modelling and Reactions, (2004), p. 236, Kluwer Academic Publishers.

(3) Yoshida, J., Microreactors, Epoch-making Technology for synthesis, (2003), pp. 141-144, CMC.

(4) Nisisako, T. and Torii, T., Microfluidic Large-Scale Integration on a Chip for Mass Production of Monodisperse Droplets and Particles, Lab on Chip, Vol. 8 (2008), pp. 287-293.

(5) Nisisako, T., Torii, T. and Higuchi, T., Droplet Formation in a Microchannel Network, Lab on a Chip, Vol. 2 (2002), pp. 24-26.

(6) Nisisako, T., Torii, T. and Higuchi, T., Formation of Liquid Droplets in a Microchannel Network for Microreactor Applications, Proceeding of the 19th Sensor Symposium, (2002), pp. 131-134.

(7) Silva, L., Tonkovich, A. L., Lochhead, R. Y., Qiu, D., Pagnatto, K., Neagle, P., Perry, S. and Lerou, J., Advanced Emulsions: Enabling Advanced Emulsion with Microchannel Architecture, American Chemical Society, Vol. 961 (2007), pp. 83-96.

(8) Murakami, Y., Arakawa, T., Jeong, E. H., Go, J.S. and Shoji, S., High Generation Rate of Uniform oil-inwater Droplets Formed by Multi-Stage Divergence Microflow Device, Proceeding of the 14th International Conference on Solid-State Sensors, Actuators and Microsystems, (2007-6), pp. 171-174.

(9) Davidson, M. R., Harvie, D. J. E. and Cooper-White, J. J., Flow Focusing in Microchannels, ANZIAM Journal,
Vol. 46 (2005), pp. 47-58.

(10) Hirt, C. W. and Gavsises, M., Volume of Fluid (VOF) Method for Dynamical Free Boundaries, Journal of Computational Physics, Vol. 39 (1981), pp. 201-224.

(11) Kobayashi, I., Mukataka, S. and Nakajima, M., CFD Simulation and Analysis of Emulsion Droplet Formation from Straight-Through Microchannels, Langmuir, Vol. 20, No.22 (2004), pp. 9868-9877.

(12) Harada, T., Suzuki, Y., Koshizuka, S., Arakawa, T. and Shoji, S., Simulation of Droplet Generation in Micro Flow Using MPS Method, Transactions of the Japan Society of Mechanical Engineers, Series B, Vol. 71, No. 711 (2005), pp. 2637-2641.

(13) Harada, T., Suzuki, Y., Koshizuka, S., Arakawa, T. and Shoji, S., Three-Dimensional Numerical Analysis of Micro Multiphase Flow Using MPS Method, Tranisactions of the Japan Society of Mechanical Engineers, Series B, Vol. 73, No. 726 (2007), pp. 437-444.

(14) Brackbill, J. U., Kothe, D. B. and Zemach, C., A Continuum Method for Modeling Surface Tension, Joumal of Computational Physics, Vol. 100 (1992), pp. 335-354.

(15) Hayashi, K., Sou, A. and Tomiyama, A., Qualitative Validity of Volume Tracking Simulation of Bubble Motion with Low Spatial Resolution, Transactions of the Japan Society of Mechanical Engineers, Series B, Vol. 72, No. 722 (2006), pp. 2410-2417.

(16) Yabe, T. and Aoki, T., A Universal Solver for Hyperbolic-Equatins by Cubic-Polynomial Interpolation, Computer Physics Communications, Vol. 66 (1991), pp. 219-232. 